\title{
ПСИХОЛОГІЧНІ АСПЕКТИ ІНТЕРСУБ'ЄКТНОЇ ВЗАЄМОДІЇ (ДО ПИТАНЬ ТЕОРЕТИЧНОГО АНАЛІЗУ)
}

\author{
Марія Наконечна \\ кандидат психологічних наук, доцент кафедри загальної та практичної \\ психології \\ Ніжинський державний університет імені Миколи Гоголя \\ 16600, Україна, м. Ніжин, вул. Графська, 2 \\ maria.nakonechna2014@gmail.com, https://orcid.org/0000-0002-2437-0853 \\ ResearcherID: R-8145-2018 \\ Світлана Александрова \\ медичний директор, лікар-психіатр вищої кваліфікаційної категорії
}

КНП «Чернігівська обласна психоневрологічна лікарня» Чернігівської обласної ради 14005, Україна, м. Чернігів, вул. Івана Мазепи, 3

SMALEKSANDROVA@ukr.net

\begin{abstract}
Анотація
У статті досліджується взаємодія як складна міжфункціональна психологічна система міжособистісних зв'язків та дій, що забезпечують взаємність як внутрішню сторону та спільне виконання задачі, як зовнішню сторону інтеракції. Доводиться, що взаємодія передбачає два основні аспекти - взаємність та спільну діяльність. Взаємність підкреслює тісний взаємозв'язок учасників інтеракції, а спільна діяльність показує множинність векторів можливих конкретно-життєвих наповнень міжособистісної взаємодії. При цьому важливим $\epsilon$ те, що предметом взаємодії та задачею, яку виконують учасники, може стати будь-що, що людина може помислити або пережити. Вивчаються різні аспекти педагогічної взаємодії, зокрема взаємні оцінні ставлення вчителя та учнів (В. Власенко, М. Коць). Наголошується, що взаємодія розглядається психологічною наукою в багатьох контекстах та аспектах - від нейробіологічного до соціального. Підкреслюється, що взаємодія як даність людського існування підкреслює те, що індивіди не можуть функціонувати ізольовано. Зокрема, вивчається негативний вплив самотності на здоров'я людей і припускається, що наявність взаємодії впливає на здоров'я людей похилого віку позитивно. Проаналізовано гіпотезу соціального мозку у взаємозв'язку з поняттям взаємодії. Виходячи з філософських підвалин, окреслюється міцний методологічний зв'язок категорії взаємодії з категоріями активності та практики, а також із поняттям взаємності у людській культурі. Діалектична єдність і протидія особистісних ставлень та дій у взаємодії виступають психологічним механізмом людської інтеракції. Розробка психологічного поняття взаємодії є важливою, оскільки, зокрема, різні види психологічних практик 3 необхідністю припускають міжособистісну взаємодію психолога та клієнта(-ів). Тому успіхи на шляху пізнання психології взаємодії означають також більш оптимальну організацію професійної діяльності психолога як людини, покликаної взаємодіяти з іншими для їхнього блага.
\end{abstract}

Ключові слова: взаємодія, діяльність, суб’єкт, взаємність, інтерсуб’єктність, особистість. 


\section{Вступ}

Сучасний світ - це складно організована динамічна система, яка знаходиться в процесі постійних змін та трансформацій, викликаних необхідністю та можливостями взаємодії на різних рівнях - від соціально-політичних до побутових, від глобальних до локальних, від індивідуальних до групових, від фізичних до психофізіологічних.

Взаємодія досліджується різними науками - філософією, соціологією, політологією, психологією, біологією, фізикою, математикою тощо. Психологічне дослідження припускає, що аналізу повинна піддаватися взаємодія як складна міжфункціональна психологічна система міжособистісних зв'язків та дій, що забезпечують взаємність як внутрішню сторону та спільне виконання задачі як зовнішню сторону інтеракції (Виготський,1983).

На нашу думку, взаємодія передбачає два основні аспекти - взаємність та спільну діяльність. Аспект взаємності як важливий конструкт людських відносин відмічав в своїх працях ще давньокитайський філософ Конфуцій (Конфуцій, 2018). Взаємність як норма людських взаємин обгрунтовувалася у «категоричному імперативі» I. Канта (Кант, 2020). Проблема спільної діяльності стала наріжною для німецької класичної філософії, де терміни діяльності, активності, суб'єкта стають фактично центральними. В ХХ столітті тема спільної діяльності розроблялася в межах діяльнісного підходу в психології (О. Леонтьєв, С. Рубінштейн, Г. Костюк).

Витоки взаємодії можна віднести до найраніших первинних суспільств, де для виживання, добування їжі і захисту треба було кооперуватися з іншими індивідами. У більш розвинених суспільствах та культурах взаємодія стає більш витонченою та пронизує собою все людське буття, адже актом взаємодії може бути будь-яка суспільна дія - від слова до різних невербальних способів самовираження.

За академічним тлумачним словником, взаємодія - це «взаємний зв'язок між предметами у дії, а також погоджена дія між ким-, чим-небудь» (Білодід, 1970: 346). Психологічний аспект погодженості дії між різними суб’єктами передбачає певне спільне поле сенсів, спільно-розподілену інтерпретацію ситуації, адже ми можемо узгоджувати дії, якщо інші суб'єкти розуміють особливості та параметри такого узгодження. Аналізуючи визначення зі словника, можна виокремити три аспекти взаємодії - діяльний взаємозв'язок між предметами, погоджена дія між предметами та погоджена дія між суб'єктами. Власне предметом психологічного інтересу виступає тут передусім взаємодія як погоджена дія між суб'єктами. Звідси інтерсуб'єктну взаємодію можна розуміти широко - як будь-яку взаємодію між будь-якими суб'єктами, але в нашій роботі підкреслюється більш вузький та сфокусований аспект суб'єктності учасників, і інтерсуб'єктна взаємодія розуміється як така, що фасилітує розвиток суб'єктності.

Філософський енциклопедичний словник пропонує таке визначення взаємодії: «Взаємодія - філософська категорія, яка відображає особливий тип відношення між об’єктами, при якому кожний з об'єктів діє (впливає) на інші об'єкти, приводячи їх до зміни, і водночас зазнає дії (впливу) з боку кожного з цих об'єктів, що, в свою чергу, зумовлює зміну його стану» (Шинкарук, 2002: 77). Оскільки взаємодія є філософською категорією, то інтерпретація ії може бути дуже широкою і водночас залежить від основних методологічних орієнтирів того чи іншого дослідження. Взаємодія як відношення об'єктів є водночас відношенням суб'єктів (за твердженням О. Лосєва суб'єкт і об'єкт є одним й тим самим (Лосев, 2014)). Прийнято виділяти суб'єкт-об'єктну та суб'єкт-суб'єктну взаємодію. Якщо при цьому розглядати предмет діяльності, то може бути відповідно суб'єкт-суб'єкт-суб'єктна та суб'єкт-об'єкт- 
суб'єктна взаємодії та їх варіації, де серединний термін позначає те, над чим працюють суб'єкти - над об'єктом (неживим предметом) чи над суб'єктом (наприклад, у виховному процесі).

Мета дослідження - 3’ясувати сутність поняття взаємодії та психологічні особливості інтерсуб'єктності.

Завдання дослідження:1) виявити теоретичні основи взаємодії як категорії та як поняття; 2) проаналізувати сучасні психологічні дослідження взаємодії; 3) вивчити сутнісні характеристики педагогічної взаємодії; 4) дослідити психологічні особливості інтерсуб'єктної взаємодії.

\section{Методи дослідження}

Основним методом дослідження виступив теоретичний аналіз. Допоміжними методами стали теоретичний синтез, індукція, дедукція, узагальнення, порівняння, абстрагування та конкретизація. В процесі дослідження використовувався метод сходження від загального до конкретного. Враховувалися діалектичні закони переходу кількості в якість (на прикладі гіпотези соціального мозку), єдності та боротьби суперечностей (на прикладі обгрунтування механізму взаємодії через ставлення та дії) та заперечення (через розгляд категорії взаємодії в історії філософської та наукової думки).

\section{Результати та дискусії}

Філософ В. Вазюлін розмежовує внутрішню та зовнішню взаємодію: «Внутрішня взаємодія в своєму повному розвитку - це така взаємодія, в якій сторони взаємодії не просто необхідно припускають одна одну, але й породжують одна іншу як дещо інше, відмінне між собою» (Вазюлин, 2006: 35). Момент породження сторонами одна іншої як дещо відмінної у випадку інтерсуб'єктності більш відповідальної, активної, рефлексивної, творчої, суб'єктної - це і є момент, характерний для інтерсуб'єктної взаємодії. Адже, за В. Вазюліним: «Зовнішня взаємодія - це така взаємодія, при якій сторони взаємодії суттєво не змінюють, не розвивають одна одну» (Вазюлин, 2006: 35). 3 цих визначень стає очевидним, що інтерсуб'єктна взаємодія є передусім внутрішньою взаємодією, яка глибоко перетворює учасників такої взаємодії, і в результаті зростає рівень внутрішньої свободи та автономії, усвідомленості та рефлексивності, творчості та відповідальності.

Український філософ С. Кримський писав: «Прагнучи втілити повноту сущого, людина виступає медіатором між матеріальним та ідеальним, потенційним та актуальним, між річчю та словом, символом та бездонною семантикою його референції. 3 цього погляду світ відбивається в історії та життєдіяльності людини як наявне буття його дарувань, тобто як світ культури» (Кримський, 2009: 13). Отже, людина живе в світі взаємодій - матеріального та ідеального, значеннєвого та смислового, емоційного та когнітивного. Світ як система елементів, модусів субстанції та контекстів розгортається як багатогранна, різноманітна взаємодія, а в проекції на людину - як культурна взаємодія, взаємодія в системі символів, сенсів та значень. Знову ж таки, можемо розглядати інтерсуб'єктну взаємодію дуже широко, адже світ одухотворений семантикою суб'єктів пізнання, але для нашого дослідження важливо, щоб інтерсуб'єктна взаємодія мала розвивальний характер, а отже ми звужуємо поняття інтерсуб'єктної взаємодії до такої, що розвиває творчі, активні, ініціативні начала в особистостях - учасниках цієї взаємодії. 
Взаємодія стала предметом особливих зацікавлень в межах психологічної школи інтеракціонізму. Дж. Мід (Мид, 2014) розмірковував про взаємодію людей, їх Ego та Alter ego, де відображення в одній особистості впливу, який вона здійснила на іншу людину, стає значущим сенсом та змістом буття. Е. Берн запровадив транзакційний аналіз, в якому аналізуються его-стани дитини, дорослого та батька, що обумовлюють характер та специфіку різних видів та способів взаємодії - від найгармонійнішої до гостро-конфіліктної (Берн, 2016).

С.Д. Максименко (Максименко, 2016) розглядав поняття особистості у взаємодії біологічної, соціальної та духовної складових розвитку. Взаємодія, згідно з поглядами С.Д. Максименка, здійснюється як реалізація нужди - споконвічного прагнення до життя та втілення. Особистість постає у єдності різних ліній ії розвитку, де біологічне стає соціальним, а соціальне - біологічним (Максименко, 2016).

Український психолог В. Власенко детально аналізував психологічні особливості взаємних оцінних ставлень вчителів та учнів (Власенко, 1995). У дослідженні акцентувалися моменти міжособистісної перцепції, але ж взаємодія, сприймання та комунікація функціонують в нерозривній єдності спільних діяльностей та спілкування людей. Автор зазначав: «...Взаємні оцінні ставлення взаємооцінки) являють собою взаємозв'язок i взаємообумовленість оцінних ставлень один до одного суб'єктів спілкування» (Власенко, 1995: 12). Тут підкреслюється особлива сторона міжособистісної взаємодії, яка виражається у взаємних оцінках суб'єктів освітнього процесу, а більш широко - будь-яких учасників взаємодії. Ці взаємні оцінки виступають важливим чинником ефективності інтеракції, адже в перцептивному боці взаємодії формується, створюється, народжується загальна спрямованість взаємних внесків у спільну діяльність, тобто взаємодію.

В. Власенко виділив такі різновиди оцінних педагогічних ставлень: 1) об'єктивний, узгоджений, врівноважений; 2) необ'єктивний, неузгоджений, неврівноважений; 3) необ’єктивний, узгоджений, неврівноважений (Власенко, 1995: 134-135). У реальній практиці освітнього процесу слід прагнути до об'єктивних, узгоджених та врівноважених оцінок. У той же час розробка питань взаємних оцінювань у педагогічній взаємодії дозволяє більш широко і багатоаспектно розглянути проблему міжособистісних інтеракцій. Типи ставлень у міжособистісній взаємодії - це невід'ємна характеристика процесу взаємної, спільної діяльності індивідів.

М. Коць зауважує: «Для професійного управління своєю комунікативною діяльністю майбутньому вчителю необхідні: уміння цілеспрямовано організувати спілкування й управляти ним, уміння спілкуватися привселюдно, уміння через правильно створену систему спілкування організувати спільну з учнями творчу діяльність» (Коць, 2020: 81). Останнє виділене автором уміння - організовувати спільну творчу діяльність - безпосередньо взаємопов'язане 3 міжособистісною взаємодією в широкому сенсі та інтерсуб'єктною взаємодією у вузькому. Якщо в монографії В. Власенка зроблено акцент на перцептивному боці спілкування та взаємодії, то М. Коць у своїй статті (Коць, 2020) підкреслює важливість комунікативних аспектів в педагогічній взаємодії. Проведене дослідження показує, що 11,5\% викладачів з вибірки мають найвищий, найбільш розвинений комунікативний потенціал, що дозволяє їм реалізувати педагогічну майстерність та гармонійно взаємодіяти із студентами (Коць, 2020). Виділено чотири градації рівнів комунікативних вмінь педагога, 3 яких найнижча, притаманна 16\% досліджуваних викладачів, виявляється в деперсоналізації та фактичній відсутності продуктивної взаємодії (Коць, 2020). 
Розглядаючи взаємодію відносно категорій психологічної практики, І. Булах зауважує: «Реалізація допомоги психолога-консультанта в процесі психологічного консультування базується на використанні основного, найпоширенішого методу консультативної взаємодії методу співбесіди 3 клієнтом» (Булах, 2012: 13). Дійсно, взаємодія як спосіб надання психологічної допомоги грунтується передусім на емпатійному вислуховуванні, на співбесіді як способі конгруентного співжиття психолога і клієнта. У широкому сенсі слід зауважити, що будь-яка форма надання психологічної допомоги є взаємодією, і водночас будь-який спосіб реалізації діяльності психолога передбачає включеність у взаємодію. Отже, психологічна практика як концептуально інтерактивна повинна розглядати різні аспекти взаємодії, зокрема професійно-орієнтованої взаємодії психолога і клієнта.

B. Васютинський (Vasiutynskyi, 2020) розглядав інтеракційні аспекти політичної психології та гендерні аспекти міжособистісної та міжгрупової взаємодії. Дослідник суттєво збагатив наукові уявлення про владу як інтераційний феномен. Згідно з В. Васютинським, інтеракція (взаємодія) пронизує всю систему владних стосунків, а індивідуальна суб'єктність може бути помислена засобами наукового дискурсу через поняття узалежнення та впорядкування.

Г. Балл (Балл, 2016) досліджував взаємодію у багатьох аспектах, зокрема через процеси соціалізації та інкультурації людей. На думку автора, успішність взаємодії обдарованої людини з оточенням залежить від внесків, які ця особистість може зробити. Таким чином, взаємодія людей постає як збагаченням досвідом, як вростання в культуру і одночасне збагачення культури індивідуально-неповторними внесками. Жива тканина соціального буття складається з взаємодій особистостей, які інтерналізують (засвоюють) та екстерналізують (привносять) значущі культурні сенси та значення.

Українська дослідниця Н. Коломієць здійснила теоретичний аналіз поняття взаємодії, підсумувавши, що це «процес спільної комунікативної діяльності, який проявляється в обміні інформацією, в організації сумісних дій, у застосуванні індивідуальних внесків (надбань), спрямованих на розв'язання спільного питання, що має своїм результатом взаємозміни їхньої поведінки, діяльності, стосунків» (Коломієць, 2018: 118). Поняття взаємодії вивчалося авторкою передусім на перетині філософських, педагогічних та психологічних досліджень. Особливо важливим є поняття взаємодії у освітньому процесі, де вчитель та учні спільно ставляться один до одного та здійснюють спільно-розподілену діяльність із засвоєння культурного досвіду людства.

Міжособистісна взаємодія відіграє найважливішу роль в житті людини. Це особливо помітно при аналізі того, як впливає відсутність взаємодії на життя та благополуччя людей. Зокрема, Й. Беллер та А. Вагнер дослідили, як самотність та соціальна ізоляція впливають на здоров’я, зокрема, який взаємозв'язок є із смертністю (Beller \& Wagner, 2018). Було виявлено, що недостатність соціальних взаємодій, що може проявлятися в самотності та ізоляції індивіда, впливає на смертність: чим більшою $є$ ізоляція, тим сильнішим є кумулятивний вплив на рівень смертності в досліджуваній вибірці (n=4 838). Можна припустити наявність зворотнього зв'язку - а саме, що творчі, ініціативні, натхненні форми активної соціальної взаємодії сприятимуть здоров'ю залучених до таких інтеракцій людей. Але для доведення такого припущення необхідна організація широкомасштабного емпіричного дослідження, бажано на вибірці людей похилого віку, як це було зроблено в роботі Й. Беллера та А. Вагнер (Beller \& Wagner, 2018). Отже, взаємозв'язок взаємодії зі здоров'ям та благополуччям людей - це тема, яка починає досліджуватися в світовій психології. Підтверджено, що 
відсутність взаємодії (самотність, ізоляція) у похилому віці негавно впливає на здоров'я осіб похилого віку. Дослідження протилежного зв'язку - наявності взаємодії на здоров'я людей ще потребуватиме масштабних психологічних студій.

Важливо проаналізувати проблему інтерсуб'єктної взаємодії в новітніх нейропсихологічних дослідженнях. Дж. Кутуньо, П. Сілва та Дж. Дісіті досліджували нейробіологічні кореляти емпатії (Coutinho, Silva \& Decety, 2014) та їх зв'язок зі здоровими міжособистісними стосунками. Перевірялася гіпотеза соціального мозку (Cozolino, 2006; Frith, 2007; Dunbar, 2012), згідно з якою людський мозок сформований у процесі еволюції під значним впливом соціальних факторів, таких як міжособистісна взаємодія, та розвивається у системі людських взаємостосунків. Відповідно до цієї гіпотези негативні соціальні впливи, наприклад травми у стосунках, негативно впливають на нейронні процеси. Досліджувана нами інтерсуб'єктна взаємодія, як можна припустити, впливатиме позитивно на діяльність нервової системи. Принаймні, у дослідженні Дж. Кутуньо, П. Сілва та Дж. Дісіті (Coutinho, Silva \& Decety, 2014) був виявлений і підтверджений позитивний вплив емпатії на мозкові процеси та периферичну нервову систему. Зокрема, автори підкреслювали, що предметом їх дослідницького інтересу є те, «як консультування та психотерапія можуть змінити соціальний мозок через заохочення більш здорових міжособистісних взаємодій» (Coutinho, Silva \& Decety, 2014: 544). Такі міркування та доведені емпірично факти дозволяють наповнити конкретним змістом висловлювання Л. Виготського про те, що вищі психічні функції існують як міжфункціональні психологічні системи, до яких включені і нейробіологічні складові (Выготский, 1983). Це дозволяє зінтегрувати дані нейробіології та психології та розглянути реальну складну природу вищої психіки.

Взаємодія пронизує все життя людини, від нейрологічних особливостей до найвищих проявів етики та моралі. 3 іншого боку, людська взаємодія важлива як для здорових, нормальних людських індивідів, так і для людей з патопсихологічними особливостями та/або проявами геніальності. Гіпотеза соціального мозку узгоджується з існуванням виявлених в дослідженнях мавп дзеркальних нейронів (Gallese, Fadiga, Fogassi, \& Rizzolatti, 1996) та даними патопсихології (психопатія як вияв антисоціального, а аутизм - асоціального мозку; «шизофренія супроводжується сильною соціальною агедонією та/або параноїдними думками в контексті міжособистісних взаємодій» (Coutinho, Silva, \& Decety, 2014: 542)). Гіпотеза соціального мозку може допомогти зрозуміти загальну спрямованість еволюції людей, іiі орієнтацію на зв'язки з іншими людьми. При цьому розвиток людського суспільства також грунтується на системах міжособистісних зв'язків та взаємин, а отже, гіпотеза соціального розвитку може врахувати як біологічні, так і соціальні тенденції розвитку людини.

Таким чином, взаємодія розглядається психологічною наукою в багатьох контекстах та аспектах - від нейробіологічного до соціального. Взаємодія як даність людського існування підкреслює те, що індивіди не можуть функціонувати ізольовано. Онтогенетичний розвиток людини показує, наскільки глобальною та фундаментальною є роль іншої людини, наприклад, матері поруч $з$ маленькою дитиною. Без інтерсуб'єктних зв'язків не зможуть адекватно розвинутися мовлення та мислення, в цілому вищі психічні функції. Поодинокі випадки, коли дитина виховувалася не людьми, а, наприклад, мавпами чи вовками - так звані «Мауглі»показують, що соціалізація та інкультурація - це вкрай важливі процеси, які мають свої сензитивні періоди та необхідні умови, зокрема наявність соціального оточення, життя людей поряд з людиною, що починає свій розвиток. 


\section{Висновки}

Взаємодія як категорія наукового пізнання ставала предметом досліджень багатьох галузей. Виходячи з філософських підвалин, можна окреслити міцний методологічний зв'язок категорії взаємодії з категоріями активності та практики, а також із поняттям взаємності у людській культурі. Ці методологічні міркування дозволяють окреслити орієнтири подальших конкретно-наукових психологічних пошуків.

Взаємодія як поняття психологічне пов'язане, на нашу думку, передусім із взаємністю та спільною діяльністю. Взаємність підкреслює тісний взаємозв'язок учасників інтеракції, а спільна діяльність показує множинність векторів можливих конкретно-життєвих наповнень міжособистісної взаємодії. Предметом взаємодії та задачею, яку виконують учасники, може стати будь-що, що людина може помислити або пережити.

Діалектична єдність і протидія особистісних ставлень та дій у взаємодії виступають психологічним механізмом людської інтеракції.

Наукова розробка психологічного поняття взаємодії є важливою, оскільки, зокрема, різні види психологічних практик - психологічне консультування, психотерапія, психодіагностика, психологічний тренінг, психопрофілактика тощо - невідворотно припускають міжособистісну взаємодію психолога та клієнта(-ів). Тому успіхи на шляху пізнання психології взаємодії означають також більш оптимальну організацію професійної діяльності психолога як людини, покликаної взаємодіяти з іншими для їхнього блага.

Перспективи подальших досліджень пов'язані з вивченням інтерсуб'єктної взаємодії та її емпірико-психологічних характеристик.

\section{Література}

1. Балл, Г. О. (2016). Успішність обдарованої людини у контексті їі взаємодії із соціокультурним середовищем. Психологія особистості, 1(7), 5-15. Режим доступу: http://nbuv.gov.ua/UJRN/Po_2016_1_3

2. Берн, Е. (2016). Ігри, у які грають люди. Харків : Книжковий клуб «Клуб сімейного дозвілля».

3. Білодід, І.К. (Ред.). (1970). Словник української мови (T. 1). Київ : Наукова думка.

4. Булах, I.C. (2012). Методичні засади взаємодії психолога-консультанта і клієнта. Міжнародний науковий форум: соиіологія, психологія, педагогіка, менеджмент, 9, 13-22. Режим доступу: http://nbuv.gov.ua/UJRN/Mnf_2012_9_4

5. Вазюлин, В.А. (2006). Логика истории взаимодействия морали и политики. Марксизм $u$ современность, 4(38), 35-37.

6. Власенко, В.В. (1995). Вчителі-учні: психологія взаємних оцінних ставлень. Київ : УДПУ ім. М.П. Драгоманова.

7. Выготский, Л.С. (1983). История развития высших психических функций. Собрание сочинений. (T. 3). Москва : Педагогика.

8. Кант, И. (2020). Основы метафизики нравственности (T. 4). Андронум.

9. Коломієць, Н. (2018). Теоретичний аналіз поняття «взаємодія». Психолого-педагогічні проблеми сільської школи, 58, 112-119.

10. Конфуцій (2018). Афоризми та вислови. Харків : Виват.

11. Коць, М. (2020). Психологічний аналіз регуляції професійно-комунікативного потенціалу майбутнього вчителя як суб'єкта педагогічної взаємодії. Психологія: реальність $i$ перспективи. Збірник наукових праџь РДГУ, 15, 77-83. 
12. Кримський, С. (2009). Ранкові роздуми. Київ : Майстерня Білецьких.

13. Лосев, А.Ф. (2014). Диалектика мифа. Санкт-Петербург : Азбука, Азбука - Аттикус.

14. Максименко, С.Д. (2016). Поняття особистості у психології. Психологія $і$ особистість, 1(9), 11-17. Режим доступу: http://nbuv.gov.ua/UJRN/Psios_2016_1_3

15. Мид, Дж. Г. (2014). Философия настоящего. Москва : Высшая школа экономики (Государственный университет).

16. Шинкарук, В.I. (Ред.). (2002). Філософський енциклопедичний словник. Київ : Абрис.

17. Beller, J., \& Wagner, A. (2018). Loneliness, social isolation, their synergistic interaction, and mortality. Health Psychology, 37(9), 808-813.

18. Coutinho, J., Silva, P., \& Decety, J. (2014). Neurosciences, empathy, and healthy interpersonal relationships: Recent findings and implications for counseling psychology. Journal of Counseling Psychology, 61(4), 541-548.

19. Cozolino, L. (2006). The neuroscience of human relationships: Attachment and the developing social brain. New York: W W Norton.

20. Dunbar, R.I.M. (2012). The social brain meets neuroimaging. Trends in Cognitive Sciences, 16, 101-102. https://doi.org/10.1016/j.tics.2011.11.013

21. Frith, C.D. (2007). The social brain? Philosophical Transactions of the Royal Society B: Biological Sciences, 362, 671-678. doi:10.1098/rstb.2006.2003

22. Gallese, V., Fadiga, L., Fogassi, L., \& Rizzolatti, G. (1996). Action recognition in the premotor cortex. Brain, 119, 593-609.

23. Vasiutynskyi, V. (2020). Gender differences in experiencing and coping with a sense of guilt in interpersonal and intergroup relations. Education: Modern Discourses, 3, 143-152. https://doi.org/10.37472/2617-3107-2020-3-14

\section{References}

1. Ball, G. O. (2016). Uspishnist obdarovanoji ljudini u konteksti jiji vzajemodiji iz sociokulturnim seredovishhem [The successfulness of a gifted person in the context of his/her interaction with the sociocultural environment]. Psihologija osobistosti, 1(7). Retrieved from http://nbuv.gov.ua/UJRN/Po_2016_1_3 [in Ukrainian].

2. Bern, E. (2016). Igri, u jaki grajut ljudi [Games peolple play]. Harkiv : Knizhkovij klub "Klub simejnogo dozvillja" [in Ukrainian].

3. Bilodid, I.K. (Ed.). (1970). Slovnik ukrajinskoji movi [Dictionary of Ukrainian Language] (Vol. 1). Kyiv : Naukova dumka [in Ukrainian].

4. Bulah, I.S. (2012). Metodichni zasadi vzajemodii psihologa-konsultanta i klijenta [The methodic foundations of the counselling psychologist's and client's interaction]. Mizhnarodnij naukovij forum: sociologija, psihologija, pedagogika, menedzhment [International Scientific Forum: Sociology, Psychology, Pedagogics, Management], 9, 13-22. Retrieved from http://nbuv.gov.ua/UJRN/Mnf_2012_9_4 [in Ukrainian].

5. Vazjulin, V.A. (2006). Logika istorii vzaimodejstvija morali i politiki [The logics of history of interaction of morality and politics]. Marksizm i sovremennost, 4(38), 35-37 [in Russian].

6. Vlasenko, V.V. (1995). Vchiteli - uchni: psihologija vzacmnih ocinnih stavlen [Teachers pupils: the psychology of mutual evaluative attitudes]. Kyiv : UDPU im. M.P. Dragomanova [in Ukrainian]. 
7. Vygotskij, L S. (1983). Istorija razvitija vysshih psihicheskih funkcij [The history of development of higher pshychological functions]. Sobranie sochinenij. (Vol. 3). Moscow : Pedagogika [in Russian].

8. Kant, I. (2020). Osnovy metafiziki nravstvennosti [The basis of metaphysics of morality] (Vol.4). Andronum [in Russian].

9. Kolomijec, N. (2018). Teoretichnij analiz ponjattja "vzajemodija" [The theoretical analysis of "interaction" concept]. Psihologo-pedagogichni problemi silskoji shkoli, 58, 112-119 [in Ukrainian].

10. Confucius (2018). Aforizmi ta vislovi [Aphorisms and quotes]. Harkiv : Vivat [in Ukrainian].

11. Koc, M. (2020). Psihologichnij analiz reguljaciji profesijno-komunikativnogo potencialu majbutnogo vchitelja jak sub'jekta pedagogichnoi vzajemodiji [The psychological analysis of professional-communicative potential of the future teacher as a subject of pedagogical interaction]. Psihologija: real'nist' i perspektivi. Zbirnik naukovih prac RDGU, 15, 77-83 [in Ukrainian].

12. Krimskij, S. (2009). Rankovi rozdumi [Morning speculations]. Kyiv : Majsternja Bileckih [in Ukrainian].

13. Losev, A.F. (2014). Dialektika mifa [The dialectics of myth]. Saint Peters burg: Azbuka, Azbuka - Attikus [in Russian].

14. Maksimenko, S.D. (2016). Ponjattia osobystosti u psychologii [The notion of personality in psychology]. Psihologija $i$ osobystist, 1(9), 11-17. Retrieved from http://nbuv.gov.ua/UJRN/Psios_2016_1_3 [in Ukrainian].

15. Mid, Dzh. G. (2014). Filosofija nastojashhego [The philosophy of the present]. Moscow : Vysshaja shkola jekonomiki (Gosudarstvennyj universitet) [in Russian].

16. Shinkaruk, V.I. (Ed.). (2002). Filosofskij enciklopedichnij slovnik [The philosophical encyclopedic dictionary]. Kyiv : Abris [in Ukrainian].

17. Beller, J., \& Wagner, A. (2018). Loneliness, social isolation, their synergistic interaction, and mortality. Health Psychology, 37(9), 808-813.

18. Coutinho, J., Silva, P., \& Decety, J. (2014). Neurosciences, empathy, and healthy interpersonal relationships: Recent findings and implications for counseling psychology. Journal of Counseling Psychology, 61(4), 541-548.

19. Cozolino, L. (2006). The neuroscience of human relationships: Attachment and the developing social brain. New York : W W Norton.

20. Dunbar, R.I.M. (2012). The social brain meets neuroimaging. Trends in Cognitive Sciences, 16, 101-102. https://doi.org/10.1016/j.tics.2011.11.013

21. Frith, C.D. (2007). The social brain? Philosophical Transactions of the Royal Society B: Biological Sciences, 362, 671-678. doi:10.1098/rstb.2006.2003

22. Gallese, V., Fadiga, L., Fogassi, L., \& Rizzolatti, G. (1996). Action recognition in the premotor cortex. Brain, 119, 593-609.

23. Vasiutynskyi, V. (2020). Gender differences in experiencing and coping with a sense of guilt in interpersonal and intergroup relations. Education: Modern Discourses, 3, 143-152. https://doi.org/10.37472/2617-3107-2020-3-14 


\title{
THE PSYCHOLOGICAL ASPECTS OF INTERSUBJECTIVE INTERACTION (TO THE ISSUES OF THEORETICAL ANALYSIS) Maria Nakonechna \\ PhD in Psychology, Associate Professor of the \\ General and Practical Psychology Department \\ Nizhyn Mykola Gogol State University \\ 2, Grafska Str., Nizhyn, Ukraine, 16600, maria.nakonechna2014@gmail.com, https://orcid.org/0000-0002-2437-0853
}

ResearcherID: R-8145-2018

Svitlana Aleksandrova

Medical Chief Executive, Psychiatrist of Higher Qualification Grade

Chernigiv regional psychoneurological hospital of Chernigiv regional council

3, Ivan Mazepa Str., Chernigiv, Ukraine, 14005

SMALEKSANDROVA@ukr.net

\begin{abstract}
The article explores interaction as a complex interfunctional psychological system of interpersonal connections and actions that provide reciprocity as internal feature of interaction and common task performance as external one. It is proven that interaction includes two basic aspects, namely reciprocity and joint activity. Reciprocity underlines close connection of participants, while joint activity shows directional multiplicity of possible specific-vital content of interpersonal interaction. Thus important thing is that anything a human being could experience or think of may become both interaction matter and task performed by its participants. Various aspects of pedagogical interaction are studied, particularly mutual judgement-based evaluations of both teachers and students. It is mentioned that interaction is studied by psychological science in many contexts and aspects, from neurobiological to a social one. It is underlined that interaction as human existence taken for granted underlines that individuals can't function in isolation. In particular, the article raises an issue of negative effects of loneliness on human health coupled with hypothesis of corresponding positive effects of interpersonal interaction on mental and somatic health of elderly people. Social brain hypothesis is analyzed in conjunction with interaction concept. Strong methodological connection of interaction as category with categories of activity and practice is outlined, as well as with the concept of reciprocity in human culture. It is argued that dialectical unity and counteraction of personal relations and actions come forward as a psychological mechanism of human interaction. Scientific development of psychological concept of interaction is important because different types of psychological practices inevitably assume interpersonal cooperation between psychologist(s) and client(s). Therefore, successful cognition of psychology of interaction means also better organization of professional activity of a psychologist as the person obliged to co-operate with others for their good.
\end{abstract}

Keywords: interaction, activity, subject, reciprocity, intersubjectivity, personality.

Подано 29.08.2021

Рекомендовано до друку 20.09.2021 